\title{
Why are estimates of global terrestrial isoprene emissions so similar (and why is this not so for monoterpenes)?
}

\author{
A. Arneth ${ }^{1}$, R. K. Monson ${ }^{2}$, G. Schurgers ${ }^{1}$, Ü. Niinemets ${ }^{3}$, and P. I. Palmer ${ }^{4}$ \\ ${ }^{1}$ Dept. of Physical Geography and Ecosystems Analysis, Geobiosphere Science Centre, Lund University, Lund, Sweden \\ ${ }^{2}$ Dept. of Ecology and Evolutionary Biology, and Coop. Inst. for Environ. Sci., University of Colorado, Boulder, CO, USA \\ ${ }^{3}$ Inst. of Agricultural and Environmental Sciences, Estonian University of Life Sciences, Tartu, Estonia \\ ${ }^{4}$ School of GeoSciences, University of Edinburgh, King's Buildings, Edinburgh, UK
}

Received: 29 February 2008 - Published in Atmos. Chem. Phys. Discuss.: 9 April 2008

Revised: 24 June 2008 - Accepted: 16 July 2008 - Published: 8 August 2008

\begin{abstract}
Emissions of biogenic volatile organic compounds (BVOC) are a chief uncertainty in calculating the burdens of important atmospheric compounds like tropospheric ozone or secondary organic aerosol, reflecting either imperfect chemical oxidation mechanisms or unreliable emission estimates, or both. To provide a starting point for a more systematic discussion we review here global isoprene and monoterpene emission estimates to-date. We note a surprisingly small variation in the predictions of global isoprene emission rate that is in stark contrast with our lack of process understanding and the small number of observations for model parameterisation and evaluation. Most of the models are based on similar emission algorithms, using fixed values for the emission capacity of various plant functional types. In some cases, these values are very similar but differ substantially in other models. The similarities with regard to the global isoprene emission rate would suggest that the dominant parameters driving the ultimate global estimate, and thus the dominant determinant of model sensitivity, are the specific emission algorithm and isoprene emission capacity. But the models also differ broadly with regard to their representation of net primary productivity, method of biome coverage determination and climate data. Contrary to isoprene, monoterpene estimates show significantly larger model-tomodel variation although variation in terms of leaf algorithm, emission capacities, the way of model upscaling, vegetation cover or climatology used in terpene models are comparable to those used for isoprene. From our summary of published studies there appears to be no evidence that the terrestrial modelling community has been any more successful in
\end{abstract}

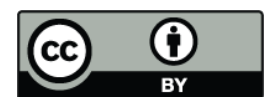

Correspondence to: A. Arneth (almut.arneth@nateko.lu.se) "resolving unknowns" in the mechanisms that control global isoprene emissions, compared to global monoterpene emissions. Rather, the proliferation of common parameterization schemes within a large variety of model platforms lends the illusion of convergence towards a common estimate of global isoprene emissions. This convergence might be used to provide optimism that the community has reached the "relief phase", the phase when sufficient process understanding and data for evaluation allows models' projections to converge, when applying a recently proposed concept. We argue that there is no basis for this apparent relief phase. Rather, we urge modellers to be bolder in their analysis, and to draw attention to the fact that terrestrial emissions, particularly in the area of biome-specific emission capacities, are unknown rather than uncertain.

\section{Introduction}

Isoprene (2-methyl-1,3-butadiene, $\mathrm{C}_{5} \mathrm{H}_{8}$ ) and monoterpenes (a diverse group of molecules made up of two isoprene units) are biogenic volatile organic compounds (BVOC) emitted from vegetation that are of widely recognized importance for atmospheric chemistry and climate. Their significance in the climate system arises from the large quantity emitted annually (e.g., the estimates of isoprene emissions summarized in Table 1 are similar in magnitude to the emission of methane) and from their fast reactivity with tropospheric oxidants (Atkinson, 2000).

Isoprene and monoterpene oxidation products are important precursors for photochemical ozone production when $\mathrm{NO}_{\mathrm{x}}$ levels are high. On the contrary, in low $\mathrm{NO}_{\mathrm{x}}$ environment, ozone can react directly with BVOC and their reaction

Published by Copernicus Publications on behalf of the European Geosciences Union. 
Table 1. Summary overview of studies of global isoprene $\left(E_{I}\right)$ and monoterpene $\left(E_{M}\right)$ emission estimates. The table includes only studies that used temperature and light dependence for the calculation of rates of isoprene emissions. Model names are in italics. A list of abbreviations is provided below; model names (or abbreviations) and a description of models and experiments can be found in the originally published work and references therein.

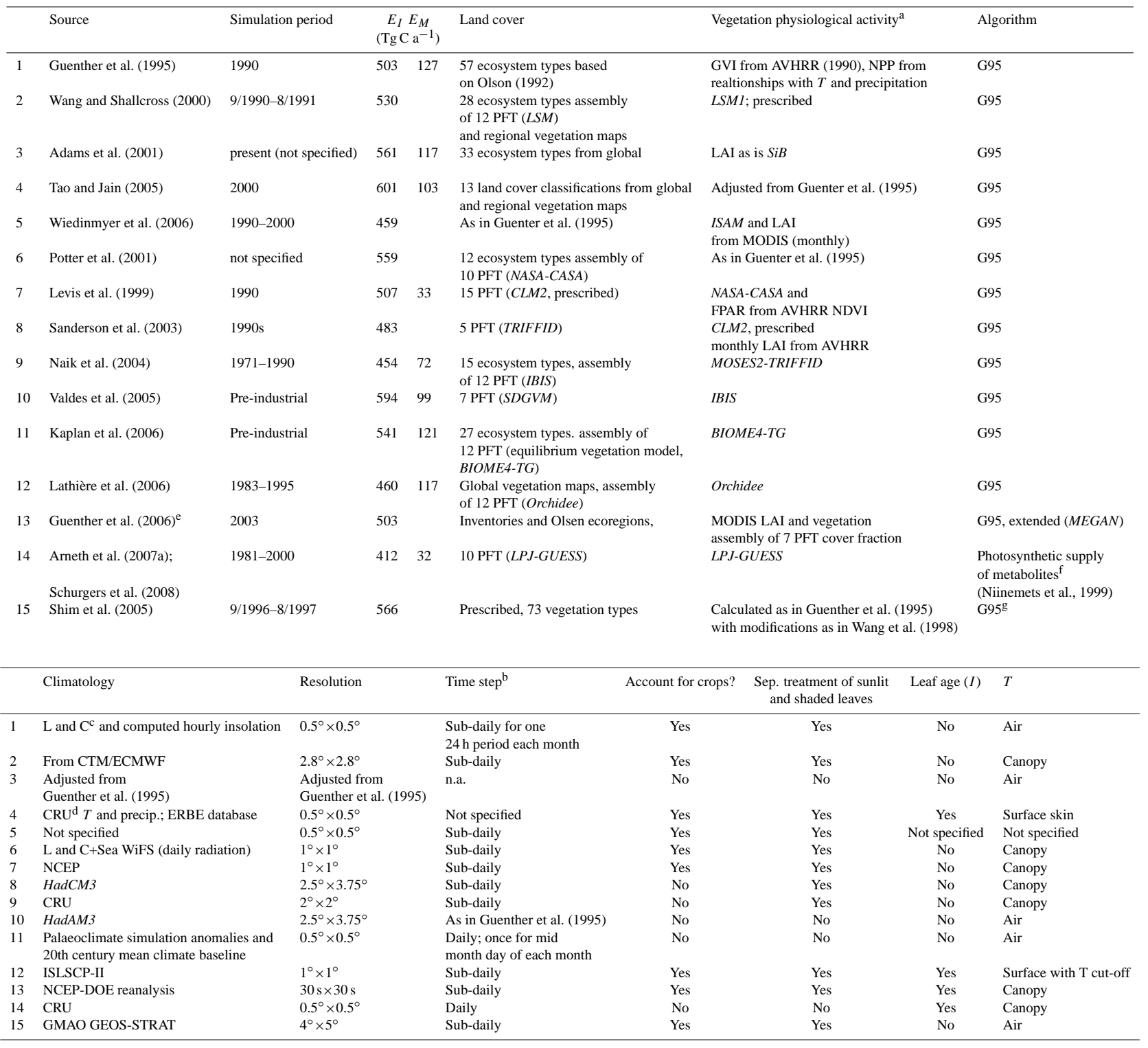

a e.g., phenology, LAI, foliar area density, NPP

$\mathrm{b}$ sub-daily time step may vary from 20 to 60 minutes depending on the model

${ }^{c}$ Leemans and Cramer, 1992: 1931-60 mean monthly temperature, precipitation and sunshine hours

${ }^{\mathrm{d}}$ http://www.cru.uea.ac.uk/

e for the MEGAN "standard" experiment

${ }^{\mathrm{f}}$ Fraction of electrons used for isoprene production; value assigned such that under standard conditions $\left(30^{\circ} \mathrm{C}, 1000 \mu \mathrm{mol} \mathrm{m}^{-2} \mathrm{~s}^{-1}, 370 \mathrm{ppm}\right)$ to result in $I=E_{I}^{*}$

$\mathrm{g}$ GOME formaldehyde inversion in combination with GEOS-CHEM are used to constrain the global estimates

Abbreviations:

\begin{tabular}{|c|c|c|c|}
\hline AVHRR & Advanced very high resolution radiometer & ISLSCP & International Satellite Land-Surface Climatology Project \\
\hline CASA & Carnegie-Ames-Stanford Approach & LAI & Leaf area index \\
\hline CLM & Community Land Model & LSM & Land Surface Model \\
\hline DGVM & Dynamic global vegetation model & LPJ GUESS & Lund Potsdam Jena General Ecosystem Simulator \\
\hline ECMWF & European Centre for Medium range Weather Forecasting & MOSES & Met Office Surface Exchange Scheme \\
\hline ERBE & Earth Radiation Budget Experiment & NCEP & National Center for Environmental Prediction \\
\hline FPAR & Fraction of photosynthetically active radiation & NDVI & Normalised Differential Vegetation Index \\
\hline GEOS & Global earth observing system & NPP & Net primary productivity \\
\hline GMAO & Global modelling and assimilation office & PFT & Plant functional type \\
\hline GVI & Global vegetation index & $\mathrm{T}$ & Temperature \\
\hline $\mathrm{HadCM}$ & Hadley Centre coupled model & TRIFFID & $\begin{array}{l}\text { Top-down Representation of Interactive Foliage } \\
\text { and Flora Including Dynamics }\end{array}$ \\
\hline IBIS & Integrated Biosphere Simulator & SDGVM & Sheffield Dynamic Global Vegetation Model \\
\hline \multirow[t]{2}{*}{ ISAM } & Integrated Science Assessment Model & $\mathrm{SiB}$ & Simple Biosphere Model \\
\hline & & $\mathrm{P}$ & Precipitation \\
\hline
\end{tabular}


products, and reduce ozone levels that way (Derwent, 1995; Atkinson and Arey, 2003). $\mathrm{O}_{3}$ acts as a potent greenhouse gas in the troposphere with an anthropogenic radiative forcing of near equal magnitude to that of methane (Forster et al., 2007). In addition, $\mathrm{O}_{3}$ is a pollutant and toxic for human beings, animals and plants; $\mathrm{O}_{3}$ causes not only a direct inhibition of crop and forestry yields (Ashmore, 2005), but may also exert a significant indirect radiative forcing effect following a phytotoxically reduced terrestrial carbon sink (Sitch et al., 2007). A number of studies have investigated the possible protective role against oxidative stress that BVOC may have (Loreto and Velikova, 2001; Velikova et al., 2005; Loreto and Fares, 2007), which so far has not been taken into account in global $\mathrm{O}_{3}$-carbon cycle-feedback calculations.

Atmospheric reactions of isoprene and monoterpenes can have an important influence on the tropospheric concentration of $\mathrm{OH}$, thereby influencing the atmospheric lifetime of methane. Reduced BVOC emissions increase the atmospheric oxidation sink strength for $\mathrm{CH}_{4}$ in atmospheric chemistry models, notably decreasing its atmospheric lifetime and hence concentration. Biochemical models cannot explain the low $\mathrm{CH}_{4}$ concentrations at the last glacial maximum (LGM) compared to the pre-industrial atmosphere based on changes in wetland sources alone. Greatly reduced LGM-BVOC emissions and $\mathrm{CH}_{4}$ lifetime helped to reproduce this long-term trend in a number of modelling studies (Adams et al., 2001; Valdes et al., 2005; Kaplan et al., 2006). It is plausible that over glacial-interglacial time scales, changes in atmospheric sink strength need to be taken into consideration for the interpretation of the icecore methane records. However, the so-far unaccounted direct $\mathrm{CO}_{2}$-leaf isoprene interaction suggests a rather more conservative BVOC emissions trend from the LGM to preindustrial conditions: the relatively larger leaf emissions at low $\mathrm{CO}_{2}$ levels offset the effects of reduced productivity and a cooler and drier climate, which complicates efforts to predict past dynamics in atmospheric $\mathrm{CH}_{4}$ (Arneth et al., 2007a).

Formation of secondary organic aerosol (SOA) is a third process of relevance for atmospheric composition and climate in which BVOC play a key role. SOA affects radiative transfer through the atmosphere and act as cloud condensation nuclei. Monoterpenes, sesquiterpenes and their oxidation products have for some years been considered to be an important precursor source, forming condensable products that are required for SOA growth (Hoffmann et al., 1997; Kulmala, 2003). More recently, isoprene oxidation products have also been identified in SOA particles. While the SOA yield from isoprene may be low, its source strength and the gas-particle partitioning characteristics of its oxidation products are efficient to the point where it may promote SOA growth at higher altitudes and enhance the SOA formation from other sources (Claeys et al., 2004; Henze and Seinfeld, 2006).
Given their central role in several important atmospheric processes, it is important that we are capable of estimating the magnitude and dynamics of surface isoprene and monoterpene emissions. Regional and global BVOC estimates have to rely on simulation experiments since, on that scale, no observational constraints exist. As a rule, these experiments use bottom-up approaches with the exception of one top-down model analysis driven by satellite remotesensing information (see Table 1, Sect. 2). It comes as no surprise that model experiments addressing the current, past or future climate or health effects of global tropospheric $\mathrm{O}_{3}$ or SOA point with recurring regularity to the magnitude and spatial distribution of biogenic precursor emissions as one of the chief sources of uncertainty (e.g., Shindell et al., 2003; Henze and Seinfeld, 2006; Liao et al., 2006; Stevenson et al., 2006). Considering this uncertainty the lack of a systematic assessment of the global simulation estimates is surprising, particularly since many of the global chemistry models need to adjust the "standard" emission estimates of BVOC downward, at least in some regions, to permit reconciliation between chemistry calculations and ozone observations (Prather et al., 2001). It is a matter of debate whether the requirement for this adjustment is a consequence of emission estimates being too high or whether it is related to shortcomings in the chemical degradation and transport mechanisms within models, although over recent years a number of chemistry models have evolved to deal with higher BVOC emissions (Prather et al., 2001; Stevenson et al., 2006).

The purpose of this paper is to review the existing global isoprene emission estimates, discuss their variation and to summarise the chief uncertainties in the simulations in terms of drivers and processes. We address the question whether the terrestrial modelling community has reached a degree of consensus on global isoprene emissions. Such a consensus would clearly attribute the uncertainties in atmospheric chemistry simulations to be dominated by unknown reaction pathways, reaction kinetics or tropospheric transport, and if so, why a similar case cannot be made for emissions of monoterpenes.

\section{Approaches to model global isoprene and monoter- pene emissions - an overview}

Table 1 provides a summary overview of annual global terrestrial isoprene and monoterpene emission estimates $\left(E_{I}\right.$, $E_{M}$ ) that have been published over the last two decades and includes present day as well as two pre-industrial estimates. The table is exclusive in the sense that it lists only studies where in the case of isoprene, both light and temperature were considered as environmental constraints on emissions. Some earlier work (Turner et al., 1991; Mueller, 1992) used algorithms that varied isoprene emissions with temperature only. However, this approach is now known to be inadequate since isoprene in leaves of green plants is 
synthesized via light-dependent processes in the chloroplastic 1-deoxyxylulose-5-phosphate (DOXP) pathway that requires redox equivalents and ATP (Lichtenthaler et al., 1997).

Broadly, global isoprene (and monoterpene) simulations may be assembled into five groups:

I) In the first, vegetation cover is prescribed from satellite remote sensing information. Changes in vegetation phenology and physiological activity, as reflected in leaf area index (LAI) and net primary productivity (NPP), influence emissions via variation in the amount of emitting leaf biomass, which is calculated from the remote sensing input (Guenther et al., 1995; Wang and Shallcross, 2000; Adams et al., 2001; Tao and Jain 2005; Wiedinmyer et al., 2006). The vegetation's capacity to emit isoprene or monoterpenes is specified at standard environmental conditions on a leaf basis, and is assigned to a number of representative plant functional types (PFT, e.g., tropical broadleaf tree, boreal needleleaf tree) or ecosystem types (e.g., tropical rain forest). The instantaneous leaf emission rate is determined from modification of the emission capacity according to the prevailing temperature and, for isoprene, light. In the seminal work presented by Guenther and co-workers (Guenther et al., 1993; Guenther et al., 1995; Guenther, 1997) widely applicable algorithms were developed as:

$E_{I, M}=\gamma E_{I, M}^{*}$,

with (for isoprene)

$\gamma=\frac{\alpha c_{L 1} Q}{\sqrt{1+\alpha^{2} Q^{2}}} \frac{\exp \frac{c_{T 1}\left(T-T_{s}\right)}{R T_{s} T}}{C_{T 3}+\exp \frac{c_{T 2}\left(T-T_{m}\right)}{R T_{s} T}}$

and (for monoterpenes)

$\gamma=\exp \left(\beta\left(T-T_{S}\right)\right)$

$E_{I} *$ and $E_{M} *$ are isoprene and monoterpene emission capacities (sometimes called "basal emission rates") referenced to a standard temperature $\left(T_{S}\right)$ of $30^{\circ} \mathrm{C}$ and (in case of isoprene) incident quantum flux density $(Q)$ of $1000 \mu$ mol photons $\mathrm{m}^{-2} \mathrm{~s}^{-1}$. $T$ is leaf temperature and $R$ is the gas constant. A number of empirical coefficients describe the light response $\left(\alpha, C_{L 1}\right)$ or the activation and deactivation energies that define the steepness of the temperature response and the location of the temperature optimum $\left(C_{T 1}, C_{T 2}, C_{T 3}, T_{m}\right)$; their values are assumed to be identical for plants from all environments. For the case of isoprene, the temperature algorithm reflects the response of the enzyme isoprene synthase to temperature (Monson et al., 1992), and the light algorithm the dependence of chloroplast electron transport on the absorbed quantum flux density. For monoterpenes, a single exponential function (with the steepness depending on $\beta$ ) is used. This function describes the short-term (minutes to a few hours) increase of the monoterpene emissions to temperature and is valid for plants that store monoterpenes in special storage tissues or organs, as found, for instance, in many (but not all) conifers (Kesselmeier and Staudt, 1999). It describes the increase of monoterpene diffusion flux out of the leaves that is associated with higher diffusion gradient between the storage pool and ambient atmosphere due to higher equilibrium monoterpene vapour pressure. The algorithm is inappropriate for species without specialized storage organs, in which monoterpene emissions are mainly controlled by the rate of monoterpene synthesis. In this latter instance, monoterpene emissions are controlled by both $T$ and light in a similar way to isoprene emissions (Staudt and Seufert, 1995; Greenberg et al., 2003; Kuhn et al., 2004).

The global emission estimates derived by upscaling these leaf-algorithms to ecosystem types (Guenther et al., 1995) have been considered as a point of reference in many of the more recent simulations, and will be referenced in the following as "G95". For isoprene and monoterpene emission capacity, most of the modelling studies conducted to date use, either directly or indirectly, the parameterisation of vegetation types provided in the G95 study.

II) A second group of models have used the G95 temperature and light algorithms in combination with dynamic global vegetation models to simulate vegetation distribution, physiological activity and phenology rather than to prescribe it (Potter et al., 2001; Levis et al., 2003; Sanderson et al., 2003; Naik et al., 2004; Valdes et al., 2005; Kaplan et al., 2006; Lathière et al., 2006). Some of these models contain mixed features, e.g., vegetation cover and variation in LAI are prescribed whereas vegetation productivity is calculated with a process-based model.

III) One recent study presents a third approach that combines prescribed, fixed vegetation cover with the use of canopy emission capacities that are expressed on ground area basis (the MEGAN model, Guenther et al., 2006). These canopy $E_{I}^{*}$ are still largely based on leaf and branch enclosure data that are spatially extrapolated using a canopy environment model but an increasing number of ecosystem scale observations are also becoming available. The MEGAN model includes an extensive expansion of the G95 algorithms by empirically specifying effects of leaf age, soil moisture, and previous days' temperature and light conditions. It requires a much wider range of standard conditions for the emission factor to be set beyond $T$ and $Q$, including standard LAI, foliage age classes, solar angle, relative 
humidity, wind speed, soil moisture, past weather conditions (Guenther et al., 2006).

IV) One study approximated global emissions using a dynamic global vegetation model framework (LPJGUESS; Smith et al., 2001; Sitch et al., 2003) with a chloroplastic isoprene model that calculates emissions coupled to photosynthetic electron transport rate $(J)$ due to the consumption of photosynthetic energy in the synthesis of volatile isoprenoids (Niinemets et al., 1999; Arneth et al., 2007a, b).

$$
I=\varepsilon J \alpha \mathrm{T}, \text { where } \alpha=\frac{\left(C_{i}-\Gamma *\right)}{6\left(4.67 C_{i}+9.33 \Gamma *\right)}
$$

Here, $\varepsilon$ is the fraction of electrons available for isoprene production, $C_{i}$ is the leaf-internal $\mathrm{CO}_{2}$ concentration, and $\Gamma^{*}$ denotes the hypothetical $\mathrm{CO}_{2}$ compensation point in the absence of dark respiration. The difference between the temperature optimum of photosynthesis and isoprene synthase is estimated by $T=\exp \left[a_{\tau}\left(T-T_{s}\right)\right]$, with $a_{\tau}=0.1$ and $T$ and $T_{s}$ as in Eq. (1). This model also accounts for the seasonality of $E_{I}^{*}$ related to growing and senescing leaves and effects of changing atmospheric $\mathrm{CO}_{2}$ concentration on emission estimates (not included in Eq. 2). Details are provided in Arneth et al. (2007b; 2008). Leaf emission capacities were assigned per PFT such that the parameter $\varepsilon$ resulted in $E_{I}=E_{I}^{*}$ when environmental conditions approach the standard conditions of G95. The simulated short-term (diurnal) response with this approach is similar in shape compared to the empirical algorithms in G95 (Arneth et al., 2007b) - predictably so, since these mimic the hyperbolic increase of photosynthesis with light, and the Arrhenius-type temperature response of enzymatic activity. The model was recently extended to monoterpenes, for which chloroplast production is calculated as in Eq. (2) and plant functional types are either assumed to emit the produced monoterpenes directly (in an "isoprene-like" fashion), or from storage organs (Schurgers et al., $2008^{1}$ ). Release from storage in the latter case is temperature-dependent in a $Q_{10}$-fashion and the average residence time $(\tau)$ is thus modified from a standard value $\left(\right.$ at $\left.30^{\circ} \mathrm{C}, \tau_{s}\right)$

$$
\tau=\tau_{s}\left[Q_{10}^{(T-T s) / 10}\right]^{-1}
$$

where $\mathrm{Q}_{10}$ is the ratio of the average residence time at temperatures $T_{1}$ and $T_{1}-10^{\circ} \mathrm{C}$, respectively.

\footnotetext{
${ }^{1}$ Schurgers, G., Arneth, A., Holzinger, R., and Goldstein, A. H.: Process-based modelling of biogenic monoterpene emissions: Sensitivity to temperature and light, Atmos. Chem. Phys., submitted, 2008
}

V) While all the above estimates rely on bottom-up approaches to estimate global totals, one analysis presented a top-down view constrained by satellite remote sensing (Shim et al., 2005). This approach is based on providing emission constraints from the short-term variations of the high-yield isoprene oxidation product formaldehyde (HCHO, derived from the Global Ozone Monitoring Experiment (GOME) satellite instrument aboard the European ERS-2 satellite) that depend on the isoprene source on the one hand, and the removal of $\mathrm{HCHO}$ oxidation by $\mathrm{OH}$ and photolysis on the other. If horizontal transport can be ignored, $\mathrm{HCHO}$ columns can be linearly related to isoprene emissions, with the regression coefficient determined from an atmospheric chemistry model (Palmer et al., 2003). In the Shim et al. study, a priori and a posteriori estimates of isoprene emissions were produced for a number of selected regions using a combination of prescribed vegetation, G95 estimates of functional type emission capacities (for the a priori run of the model) and a chemical transport model.

\section{Global isoprene estimates and model uncertainties: processes and drivers}

In view of the diverse combination of emission algorithms, climatic input, description of vegetation cover and physiological activity, and simulation period (Table 1) the annual emission estimates and/or the regional emission patterns would be expected to vary widely; yet, at least for isoprene, this expectation emerges as a seemingly unfounded preconception. The average annual total of the studies summarized in Table 1 is $516 \mathrm{Tg} \mathrm{Ca}^{-1}$, with a standard deviation of little more than ten percent of this value $\left(55 \mathrm{Tg} \mathrm{Ca}^{-1}\right)$. Three of the 14 estimates (Tao and Jain, 2005; Valdes et al., 2005; Arneth et al., 2007a) lie clearly outside the range defined by the standard deviation $\left(460-570 \mathrm{Tg} \mathrm{Ca}^{-1}\right)$. The small standard deviation is remarkable when considering that, for instance, model intercomparisons of net primary productivity values still varied with a standard deviation of close to $20 \%$ after driving variables were made to converge as far as possible (Cramer et al., 1999). The overall span between the minimum and maximum isoprene estimate is $189 \mathrm{Tg} \mathrm{Ca}^{-1}$ which is nearly similar to the variation that can be introduced within a single model depending on variation in driving variables (Guenther et al., 2006). There is also little divergence regarding the chief source areas: those studies that break down global emissions by region attribute the largest isoprene source, between approximately 70 and $90 \%$ of global totals, to be located in tropical ecosystems.

Curiously, a similar picture does not emerge from simulation estimates of global monoterpene emissions. For this class of compounds, the variation around the mean is considerably larger, with estimates varying by a factor of $c$. four 


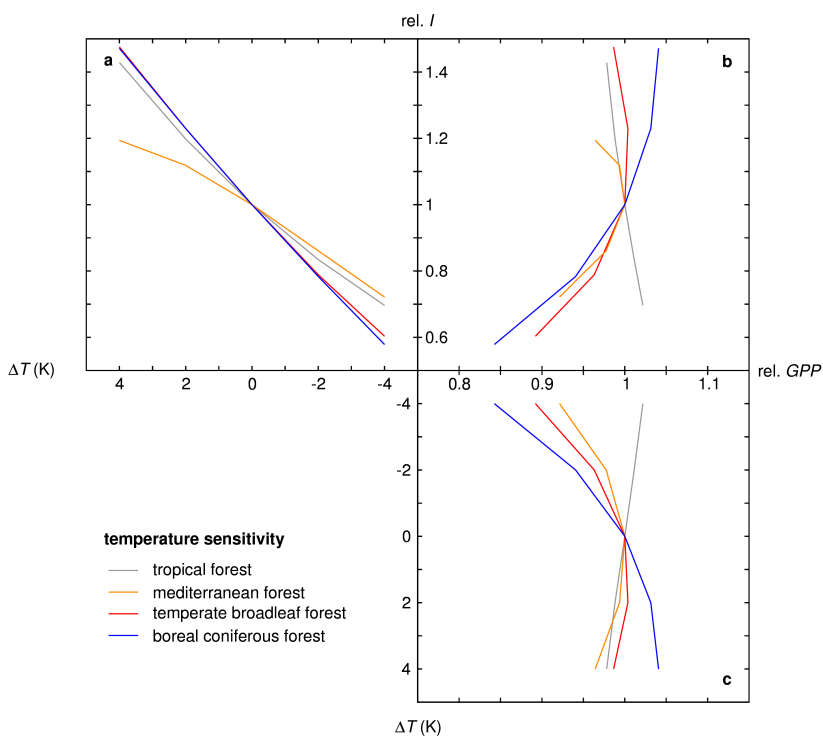

Fig. 1. Response of canopy isoprene emissions $(I)$ to a change in temperature $(\Delta T$, panel a) and the effects of the corresponding changes in gross primary productivity (GPP) on $I$ (panel b), and the interactions of GPP and $T$ (panel c). The distribution of plant functional types, climate and $\mathrm{CO}_{2}$ concentration were prescribed using the average of the years 1981-2002 (obtained from standard model runs as in e.g., Arneth et al (2007a)), and temperature was decreased and increased by $2 \mathrm{~K}$ and $4 \mathrm{~K}$ on an annual basis. $I$ and GPP are expressed relative (rel) to their 1981-2002 averages, while $\Delta T$ is the difference to the average $T$ over this period. The difference between the temperature optimum of photosynthesis and isoprene emissions is accounted for as described in Arneth et al. (2007b). The y-axis of panels a and b denotes rel $I$ in response the changes in $T$ and GPP, the $\mathrm{x}$-axis of panels $\mathrm{c}$ and $\mathrm{b}$ shows rel GPP. Locations are:

1. Tropical forest, Brazil, $40^{\circ} \mathrm{W}, 10^{\circ} \mathrm{S}$;

2. Mediterranean forest, Spain, $5^{\circ} \mathrm{W}, 38^{\circ} \mathrm{N}$;

3. Temperate broadleaf forest, Germany, $10^{\circ} \mathrm{E}, 50^{\circ} \mathrm{N}$;

4. Boreal coniferous forest, Canada, $120^{\circ} \mathrm{W}, 60^{\circ} \mathrm{N}$.

between minimum and maximum, rather than by 1.5 as for isoprene. The standard deviation $\left(37 \mathrm{Tg} \mathrm{Ca}^{-1}\right)$ is $40 \%$ of the mean $\left(91 \mathrm{Tg} \mathrm{Ca}^{-1}\right)$. For monoterpene emissions, which are modeled to depend exponentially on temperature only, a small change in temperature will have a large impact on projected emissions. This may, to some extent, explain why there is much greater variation in global emission estimates than those for isoprene but it is unlikely to be the full explanation since isoprene also responds steeply to temperature increases before reaching the temperature optimum of emission. Calculated global gross or net primary productivity (GPP, NPP) is generally not stated in the published papers. This is unfortunate: LAI, GPP and NPP are closely linked and since they are a main factor influencing emissions it would be instructive to being able to judge how much of the variation in emission estimates might be due to variation in productivity.

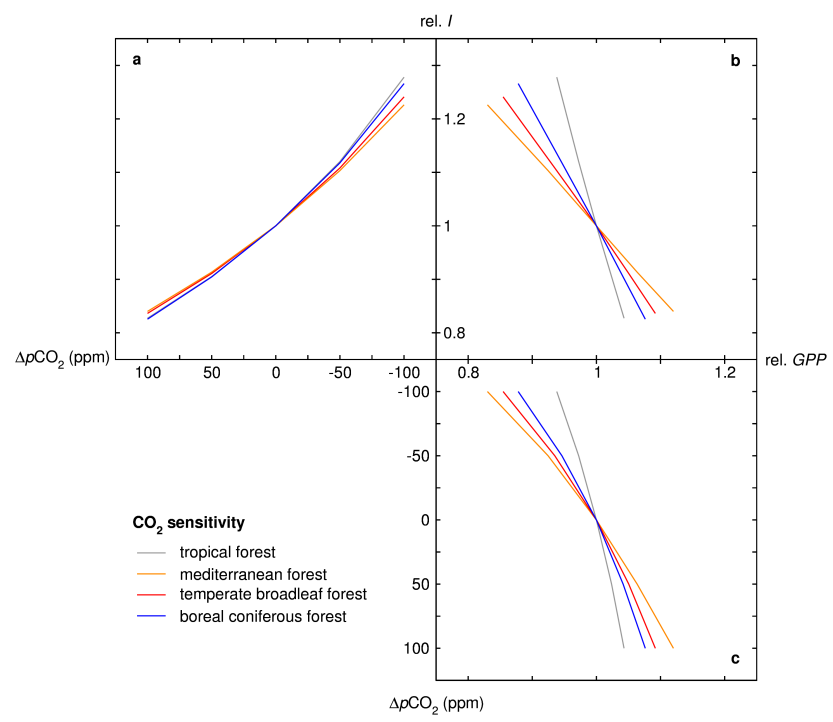

Fig. 2. As in Fig. 1 but varying atmospheric $\mathrm{CO}_{2}$ concentration by $50 \mathrm{ppm}$ and $100 \mathrm{ppm}$.

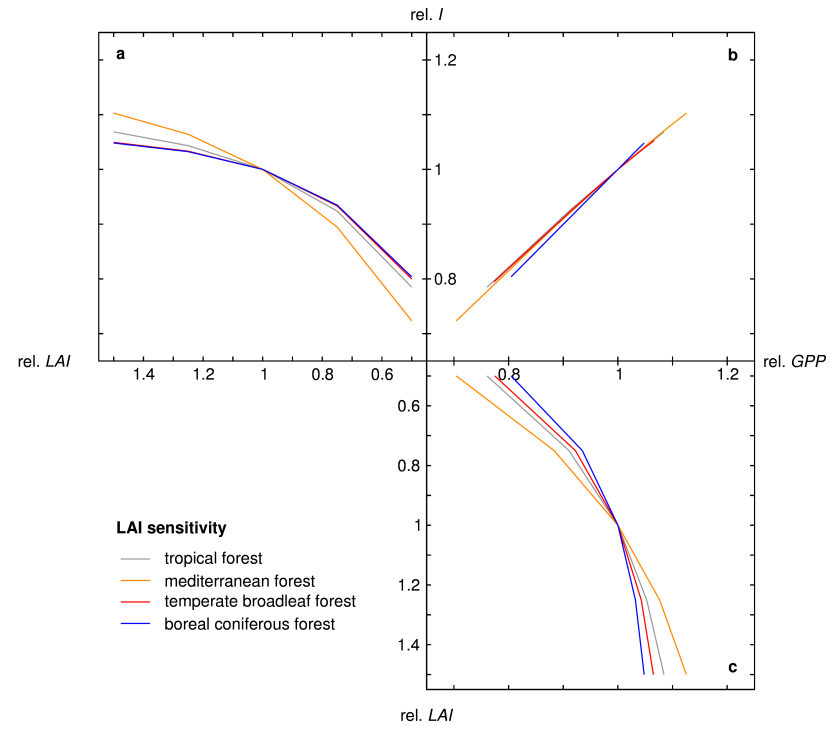

Fig. 3. As in Fig. 1 but varying leaf area index by $25 \%$ and $50 \%$.

Figures 1-3 aim to provide an illustrative example, showing changes in relative isoprene emission rates for example locations, calculated with LPJ-GUESS combined with a process-based isoprene model (Arneth et al., 2007b) in response to changing temperature (Fig. 1), atmospheric $\mathrm{CO}_{2}$ concentration (Fig. 2) and leaf area index (Fig. 3), while keeping the other parameters fixed. Increasing temperature enhances emissions at all example environments which in LPJ-GUESS results from the temperature stimulation of photosynthesis and the higher temperature optimum of isoprene synthesis compared to that of electron transport (Arneth et al., 2007b). In the temperate and boreal environments the $T$-optimum of modelled GPP is at or above the 
present temperature (panel c). At the Mediterranean location, GPP starts to decline at temperatures more than $c .2$ degrees above present which causes the change in the slope of the $I_{\text {rel }}$ vs. $\Delta T$ relationship (panel a). At tropical locations GPP decreases slightly with increasing temperature. Here photosynthesis begins to operate below the temperature maximum and hot temperatures promote the oxygenation of Ribulose1,5-bisphosphate relative to its carboxylation (Hickler et al., 2008). At all locations a 4 degree temperature increase is still below the $T$-maximum of isoprene emissions which is mainly defined by the $T$-maximum of isoprene synthase. Effects of $\mathrm{CO}_{2}$ fertilisation on GPP are visible at all locations, being most pronounced in the Mediterranean forest (Fig. 2, panel c) where increasingly conservative water use in a high $\mathrm{CO}_{2}$ world becomes advantageous. But despite increasing GPP, $I$ declines with increasing $\mathrm{CO}_{2}$ concentration, owing to the direct $\mathrm{CO}_{2}$ inhibition that is included in the model and that overrides the fertilisation effect (panels a,b; Arneth et al., 2007a, b). Finally, for the effect of LAI we found relatively similar patterns at all locations with the response being most sensitive in Mediterranean environments, likely because simulated LAI there was lowest of the four locations (3.4) and relative changes cause thus the largest effects on absorbed radiation.

With one exception, the above-referenced studies include the G95 algorithms, or their modifications, as a core scheme to calculate the emission response to variation in temperature and (in case of isoprene) light. Putting forward an initial raison d'être for the surprisingly small variation in isoprene emission estimates thus seems straightforward: the short-term variation in leaf-level emissions (i.e. the emission algorithm) is of overriding importance, such that experiments that are based on the same emission algorithm result in fairly similar totals with some additional variation introduced by differences in vegetation cover, effects of environmental stress on emission capacity, leaf-to-canopy upscaling, or by accounting for effects of leaf age, seasonality and/or past weather.

Given this line of reasoning, however, we are left with a puzzle. The studies in Table 1 use climate inputs from a range of sources that differ significantly in their monthly or daily light, temperature and precipitation patterns, particularly in the tropical regions. They also derive land cover from different methods and differ consequently in the relative areas of important regions like the tropical evergreen forests and savannas. Moreover, emissions are in some cases reported for single years, and in others for periods of varying length. If the short-term response of $E_{I}$ (and hence the algorithm used) indeed was of overriding importance then, considering the very strong sensitivities of $E_{I}$ to temperature and light, the different climate inputs should be the cause for sizeable discrepancy between the emission estimates. The observed lack of model variation must lead us to two alternative explanations:
1. the sensitivity of the models to variations in the instantaneous light and temperature drivers is much less than anticipated, and we must look to other model components to explain their convergence towards similar values;

2. discrete model components like vegetation characteristics, climatology or emission algorithms have the potential to independently increase or decrease in compensatory fashion, such that the total net emissions remains relatively constant.

Below we briefly summarise the possible chief sources of model uncertainties to shed some light on possible causes for model discrepancies, and for compensating processes. Where appropriate/possible, we use our own model results to illustrate the effects some of these potential causes might have.

\subsection{Emission algorithm}

The Guenther et al. light and temperature algorithms (Eq. 1) require parameterisation with regard to the coefficients $\alpha$, $\mathrm{C}_{L 1}, \beta, C_{T 1}, C_{T 2}, C_{T 3}$ and $T_{m}$. While the sensitivities of isoprene and monoterpene emissions to light and temperature are high, these algorithms have reproduced observed shortterm variation in leaf emissions in a wide range of conditions and it is generally assumed that isoprene and monoterpene emitting species each have a similar light and/or temperature dependence (Wiedinmyer et al., 2004). As demonstrated in Guenther et al. (1993) even minor changes in the values chosen for $T_{m}$ (isoprene temperature response) or $\beta$ (monoterpene temperature response) will affect daily and maximum fluxes substantially. Furthermore, changes in the values for $C_{L}$ (isoprene light response) or $C_{T 1}$ result in a (near)corresponding change of maximum emissions (not shown). A number of observations in boreal or subarctic environments have suggested that emissions of isoprene and monoterpenes may increase more steeply with warmer temperatures than indicated by the standard parameter values (Hakola et al., 1998; Rinne et al., 2000; Janson and de Serves, 2001; Ekberg et al., 2008²). In principle, this would be a plausible adaptation to a cool growth environment but to date the available data is too limited to derive a firm conclusion in that respect. At a study location in northern Sweden, growing season total leaf emissions from sedges were estimated to differ by approximately a factor of two between calculations that used the standard settings, and calculations that used values obtained by fitting Eq. (1) to measurements (Ekberg et al., 2008). We are not aware of a systematic analysis of changes in these coefficients on global emissions.

Recently, there has been some recognition of the role of seasonal leaf development or weather conditions

\footnotetext{
${ }^{2}$ Ekberg, A., Arneth, A., Holst, T., Hayward, S., and Hakola, H.: Leaf isoprene emissions from two subarctic wetland sedges, Biogeosciences, submitted, 2008.
} 
accumulated over a period of few days to weeks in modifying these coefficients (see also Sect. 3.3). Guenther et al. (1999, 2006) suggested a response of emissions to medium-term growth environment (few days to weeks) that affect not only emission capacity but also the shape of the light response and the temperature optimum of emission. An increase in average temperature of the past 15 days from 20 to $35^{\circ} \mathrm{C}$ would increase emission capacity approximately five-fold, and move the temperature optimum of emissions by $c .7^{\circ} \mathrm{C}$ (Guenther et al., 1999; Wiedinmyer et al., 2004, their Fig. 4). For a study region in equatorial Africa a difference of 11$12 \%$ in isoprene emission estimates was introduced by varying the light and temperature response dynamically in response to the growth environment (Guenther et al., 1999). But there is as yet little empirical basis on which to inform such modification. Therefore, for most studies in Table 1 there is little potential for the algorithms themselves to generate variance among model predictions; only to the extent that the temperature and light inputs vary, as described above.

For isoprene, it has been shown that the short-term response of the G95 algorithms and those where emissions are linked to photosynthesis do not result in significant differences in short-term emission responses on the leaf scale (Arneth et al., 2007b). For monoterpenes, a large difference was found when taking into account the fact that many broadleaf deciduous emitters do not store monoterpenes over long-term in specific organs, but rather emit them in an "isoprene-like" fashion (Staudt and Seufert, 1995; Schurgers et al., 2008). Further differences related to the algorithm will emerge when transient responses of emissions to global change are investigated since on decadal and longer time scales the possible effect of a direct $\mathrm{CO}_{2}$-isoprene interaction that has been demonstrated in a range of laboratory experiments (Rosenstiel et al., 2003; Possell et al., 2005) becomes apparent. Such an effect could result in greatly changed past and future emission estimates (Arneth et al., 2007a). For contemporary global totals the differences in emission algorithm alone should not be a chief cause of difference between models.

\subsection{Emission capacity}

Everything else being equal, total emissions depend linearly on the specified emission capacities (Eqs. 1 and 2). In global studies, the values of $E_{I}^{*}$ and $E_{M}^{*}$ are generally adopted from the recommendations by Guenther et al. (1995) that were based on aggregated leaf enclosure and atmospheric concentration measurements. These original recommendations included default values for $E_{I}^{*}$ and $E_{M}^{*}$ for a number of ecosystem classes for which by the mid 1990 field observations had not been available. The values for the original emission factors are relatively regularly spaced. They represent average emission categories and an emission factor of (for instance) 8 reflects literature values that may range from 6 to 12 . This simplifies the process of combining different emission factor databases with various levels of uncertainty and number of samples and allows to group sources into finite number of categories (Guenther, personal communication, 2008). Values for $E_{I}^{*}$ have since been updated, based on new observations that have become available over the last two decades, and converted from leaf area to a grid area (canopy) basis (Guenther et al., 2006). However, for most ecosystems and vegetation types measurements of BVOC emissions are still scarce or absent (Guenther et al., 2006).

Assigning values of $E_{I}^{*}$ to a certain PFT or vegetation class can easily cause large variation in modelled emissions, since the vegetation categories and the number of plant functional types may differ. Due to the scarcity of measurements and the inevitable lumping of a large number of plant species into functional groups, the value to be used requires considerable subjective judgement by the researcher. The effect this may have can be illustrated by four studies that used relatively similar PFT categories (Table 1). Two of the studies (Naik et al., 2004; Arneth et al., 2007a) used full DGVM features for simulation of potential natural land cover and vegetation physiological activity, while the other two calculated physiological activity dynamically but used a prescribed vegetation cover including crop area (Levis et al., 2003; Lathière et al., 2006). In these experiments the authors had chosen to assign in some cases very different values of $E_{I}^{*}$.

For instance, Levis et al. (2003) use the same value of $24 \mu \mathrm{g}(\mathrm{C}) \mathrm{g}$ (leaf foliar mass $)^{-1} \mathrm{~h}^{-1}$ for tropical, temperate and boreal broadleaf deciduous and evergreen PFTs. With the exception of the two herbaceous C3 and C4 PFTs, Arneth et al. (2007a) adopted the values of Naik et al. (2004), including an $E_{I}^{*}$ of $45 \mu \mathrm{g} \mathrm{g}^{-1} \mathrm{~h}^{-1}$ for tropical, temperate and boreal broadleaf deciduous vegetation. Lathière et al. (2006) chose 24, 45 and $8 \mu \mathrm{g} \mathrm{g}^{-1} \mathrm{~h}^{-1}$ for the tropical, temperate and boreal broadleaf deciduous PFT, respectively. All four studies assigned a value of $24 \mu \mathrm{g} \mathrm{g}^{-1} \mathrm{~h}^{-1}$ to tropical evergreen woody vegetation. The calculated annual isoprene totals varied merely between 412 and $507 \mathrm{Tg} \mathrm{Ca}^{-1}$, despite $E_{I}^{*}$ varying by a factor of two (tropical broadleaf deciduous) to more than five (boreal broadleaf deciduous). The large differences in the latter are of little consequence for global totals - all four studies attribute less than $5 \%$ of the global emissions to boreal ecosystems due to the overall short growing season and relatively low temperatures - but they will become a key factor in regional experiments, e.g., when studying effects of BVOC emissions on secondary organic aerosol formation (Tunved et al., 2006) or effects of global warming on northern latitude ecosystems (Ekberg et al., 2008). By contrast, PFT basal rates for tropical trees matter greatly not only on regional but also on global scale with typically $70-80 \%$ of total isoprene emissions attributed to originate from tropical ecosystems. The use of a value of either 24 or $45 \mu \mathrm{g} \mathrm{g}^{-1} \mathrm{~h}^{-1}$ for tropical deciduous trees should therefore cause major model-to-model differences. In LPJ-GUESS, global totals are reduced by $15 \%$ when the lower $E_{I}^{*}$ is used to simulate emissions from tropical raingreen ecosystems (Schurgers, unpublished). 
Variation of $50 \mathrm{Tg} \mathrm{Ca}^{-1}$ or more could also be attributed to dissimilar $E_{I}^{*}$ of herbaceous vegetation alone, despite the fact that grasses and herbs are generally considered to have notably lower emission potential than woody vegetation (see next paragraph), particularly the $\mathrm{C}_{4}$ grasses which to our knowledge so far have not been found to emit isoprene. Naik et al. (2004), for instance, excluded these PFT as emitters and commented that their $50 \mathrm{TgCa}^{-1}$ difference compared to the G95 estimate could be accounted for by this effect. By contrast, Lathière et al. (2006) assigned relatively high emission potential to $\mathrm{C}_{3}$ and $\mathrm{C}_{4}$ grasses ( 16 and $24 \mu \mathrm{g} \mathrm{g}^{-1} \mathrm{~h}^{-1}$ ) and calculate $90 \mathrm{Tg} \mathrm{a}^{-1}$ from these two PFTs. They state that their similar global total emissions to the estimates presented by Naik et al. (2004) was due to compensation of their higher herbaceous $E_{I}^{*}$ by their use of prescribed vegetation that included crop cover with low $E_{I}$. In LPJ-GUESS, an emission potential of 0 vs. $24 \mu \mathrm{g} \mathrm{g}^{-1} \mathrm{~h}^{-1}$ for $\mathrm{C}_{4}$ grasses results in an overall decrease of emissions by $10 \%$ (Schurgers, unpublished). Clearly, differences in the way that modellers parameterise the emission capacities of various plant functional types can have a relatively large influence on the estimation of global emissions. One reason that the model results reported to date reflect such striking similarities is that they have relied on parameterisation schemes that are highly adaptable with regard to the set emission capacities, reflecting the large uncertainty in the values chosen for a PFT.

\subsection{Weather conditions of previous days and acclimation of emission capacities}

The seasonality of emissions is sometimes illustrated as January and July maps of emissions per unit area, but so far has rarely been reported as seasonal global totals. It is not possible to judge on how model-to-model differences will affect the seasonality on top of the annual sums. Several studies have demonstrated that foliar isoprene emission rate is not only determined by present weather conditions but also by cumulative conditions over a period of several days prior. Even in mature leaves (see Sect. 3.7), emission capacity can vary over a period of few days by a factor of three to four (Monson et al., 1994; Geron et al., 2000; Hanson and Sharkey, 2001; Ekberg et al., 2008). This effect has only been accounted for in one of the global emission estimates (Guenther et al., 2006) postulating a linear dependency of $T_{\max }$ on past $240 \mathrm{~h}$ average temperature, and an exponential relationship with $T$ of the past 24 and $240 \mathrm{~h}$ - in both cases relative to present temperature. Emissions depend also on past 24 and $240 \mathrm{~h}$ light conditions. For simulations with the MEGAN model, seasonal variation (for instance) in tropical biomes varied by a factor of three as a result of incorporating past weather effects, by contrast to previous estimates where seasonal variation was nearly absent (Guenther et al., 1995, 2006). The shape of these responses - and the required complexity in the algorithm - is highly uncertain. It could be argued that disregarding past weather conditions has a fairly small influence averaged over the course of a year, if the emission capacity used reflects the appropriate seasonal average, since in that case emissions will be underestimated during some, and overestimated during other parts of the year. This has been found for a local study at a subarctic wetland (Ekberg et al., 2008), where the amplitude of summer leaf isoprene emission rates was simulated to vary around a factor of four or eight depending on whether or not short-term weather effects in emission capacity were included. The annual emission totals were hardly affected, but the short-term variation in emission capacity should not be ignored when emissions are linked to atmospheric chemistry calculations where a high temporal resolution is required.

On the global scale, Tao and Jain (2005) report annual emissions similar to Guenther et al. (2006), using the MEGAN emission factors but excluding short-term weather modifications. The inclusion of past temperature regimes as a modelled effect on the isoprene emission capacity is currently based on only one study which investigated the response of $T_{\max }$ to growth temperature at the leaf level with aspen trees (Monson et al., 1992). Thus, it is unclear at present how a broader consideration of these effects can improve projections of emissions, or the degree to which its consideration will cause model projections to diverge from one another. As emphasized by Guenther et al. (2006), simulations that include the effects of past weather will lead to an enhanced rate of emissions in the future, since not only "present" but also 'past' temperatures in warmer climate scenarios will change. There is clearly room for further development as to how representative species of various plant functional types respond with regard to $T_{\max }$ and past temperature conditions, and the effect of such responses on model projections.

\subsection{Vegetation cover}

Although some C3 grasses, sedges or herbaceous vegetation emit significant amounts of isoprene (Kesselmeier and Staudt, 1999; Bai et al., 2006; Ekberg et al., 2008), by far the largest proportion of isoprene emission originates from woody vegetation. Azolla, a highly emitting fern is frequently found growing alongside non-emitting rice in aquaculture. A small number of agriculturally important species have high isoprene emission rates (for instance velvet bean or tree-crops like poplar, willow, eucalypt and oil palm), but most of the widely planted crop species are relatively insignificant in terms of their isoprene and monoterpene emissions (Kesselmeier and Staudt, 1999). Correspondingly, emission capacities specified for agricultural ecosystems tend to be relatively low, and where annual crops replace natural forest ecosystems rather than natural grasslands, a significant difference in simulated emissions is to be expected. 
Isoprene emission estimates for Europe differ by a factor of three for potential natural forest cover vs. real forested area (Arneth et al., 2008). Lathière et al. (2006) report reduction of global isoprene emissions by nearly $30 \%$ in a simulation where the two tropical PFTs had been replaced with tropical grasses and crops, even though $E_{I}^{*}$ of the former was assigned a similar value to that of the tropical tree PFT. Despite the clear differences that emerge in these experiments, the studies cited in Table 1 do not indicate a systematic landcover effect that might override other model-to-model differences. Some of the estimates using potential natural vegetation cover, and present productivity and climate, are lower or close to the average of all studies (Sanderson et al., 2003; Naik et al., 2004; Arneth et al., 2007a). Two studies that were performed using potential natural vegetation cover but preindustrial climate and productivity were at the upper end of the range presented in Table 1, although the climate driving the simulations should be notably cooler than today's (Valdes et al., 2005; Kaplan et al., 2006). These estimates were similar in magnitude to some of the studies that accounted for cultivated land with non-woody crops that are low isoprene emitters (Tao and Jain, 2005; Potter et al., 2001).

Overall, there appears to be a discrepancy between how intuition informs us about the effects of model specification of vegetation cover on the projected global isoprene emission rate, and what actually emerges from the model runs. From our analysis, the sensitivity of model performance to spatially-prescribed vegetation cover schemes is lower than anticipated. It is possible that compensation occurs within the composition of specified biomes with regard to specific plant functional types that vary in their associated isoprene emission capacities. However, without more specific information on how each biome or vegetation cover class is composed in each model it is difficult to take this component of the analysis further.

\subsection{Leaf area index and leaf to canopy upscaling}

For a given vegetation cover, large variations in emissions can be expected from the prescribed or calculated (sunlit) leaf area index and specific leaf area. This arises from the dependence of $E_{I}$ or $E_{M}$ on total canopy foliage (Guenther et al., 1995). Differences to the G95 isoprene prediction of $503 \mathrm{Tg} \mathrm{Ca}^{-1}$ have been discussed in light of differences in estimated seasonality of foliar area density, particularly in tropical drought-deciduous ecosystems (Potter et al., 2001) or overall lower leaf biomass (Naik et al., 2004). Within one model, annual emissions have been shown to deviate from $-11 \%$ to $+29 \%$ around a standard simulation, depending on the specified LAI (Guenther et al., 2006).

Unsurprisingly, due to the dependence of isoprene emissions on light, the total amount of radiation absorbed by the canopy has also been found to have a large effect on the total emissions estimates (Lathière et al., 2006). Some studies have shown that the number of vertical levels in the canopy has a small influence on the emissions (Guenther et al., 1995; Lamb et al., 1996), but this observation depends on the type of the radiative transfer which is represented by very dissimilar approaches in the models (ranging from Beer's law to a relatively detailed treatment of canopy layers). For models that use the fraction of light absorbed by the canopy $\left(f_{Q}\right)$ for scaling, rather than multiply leaf emissions by LAI, a critical step is the conversion of the incident quantum flux density of $1000 \mu \mathrm{mol} \mathrm{m}^{-2} \mathrm{~s}^{-1}$ that is used for specifying $E_{I}^{*}$ into the equivalent $f_{Q}$. In LPJ-GUESS, emissions vary proportionally to assumed $f_{Q}$ values under standard conditions, which introduces considerable uncertainty into the calculations; at this stage a value of $f_{Q}=0.42$ is used which is analogous to the assumption that a leaf close to the top of the canopy has a $\gamma$ (Eq. 1a) of unity when $Q=1000 \mu \mathrm{mol} \mathrm{m}^{-2} \mathrm{~s}^{-1}$ (Guenther et al., 1999). Despite the sensitive response of emissions to radiation, it is unlikely that the light dependence of isoprene emissions most strongly controls the emissions owing to the dissimilar amount of sunlit leaves in different light transfer models. Still, a relatively smaller or larger proportion of the canopy that is light limited provides an additional constraint that can dampen the emissions on top of the temperature response.

For canopy temperature, the crucial aspect is whether air or canopy temperature is used, particularly in canopies that have a high boundary layer resistance and low transpiration rate (Monteith and Unsworth, 1990). The potentially high sensitivity of isoprene or monoterpene emissions to the temperature specification scheme is due to the exponential dependence of emission rates on temperature. The global emission estimates summarized in Table 1 used a range of temperatures, some assuming air temperature to approximate canopy temperature, some including a leaf energy balance scheme in their canopy vertical transfer model, while others are based on skin surface (at the surface-atmosphere interface) temperature. The latter may exceed canopy temperature significantly, and a $2^{\circ} \mathrm{C}$ cap for the surface to air temperature difference was imposed e.g., by Lathière et al. (2006) but not so by Tao and Jain (2005). Lathière et al. found that increasing the average global surface temperature by $1^{\circ} \mathrm{C}$ led to an increase of isoprene emissions by $11 \%$ (Lathière et al., 2006). In LPJ-GUESS, the emissions are calculated based on a leaf energy balance model (Schurgers et al., 2008) and annual totals vary by less than $10 \%$ between years that differ in average temperature of around $1{ }^{\circ} \mathrm{C}$ during the period $1981-$ 2000 , if the $\mathrm{CO}_{2}$ concentration is kept constant (Schurgers, unpublished). Guenther et al. (2006) draw attention to the fact that simulations are less sensitive to air temperature variation if the model uses leaf temperature as the actual driver. This arises from the fact that leaf temperature is influenced by conductance (and hence soil moisture), radiation absorbed by the leaf, and the assumed boundary resistance of the leaf. 


\subsection{Simulation period and climatology used}

Keeping in mind the strong dependence of emissions on temperature it would seem to follow logically that the average climate during the period of simulation should have a sizeable impact on emissions. For a 12-year simulation, Lathière et al. (2006) calculated (at constant $\mathrm{CO}_{2}$ ) a range in global isoprene emission rates from $435-478 \mathrm{Tg} \mathrm{Ca}^{-1}$, with a positive correlation between isoprene emissions and globally averaged air temperature. Over a period of 20 years the interannual variation in emission was largely due to climate variability in the study of Naik et al. (2004; coefficient of variation over the simulation period was $2.5 \%$ for isoprene, $4.1 \%$ for monoterpenes), less so than the variation in productivity in response to atmospheric $\mathrm{CO}_{2}$ levels. Levis et al. (2003) found a variation of 5\% of annual global averages in ten years while Guenther et al. (2006) reported variations of -14 to $+13 \%$ around the standard run for a range of 20th century climatologies covering 4 to 80 years. Global annual totals in LPJ-GUESS vary by $25 \mathrm{Tg} \mathrm{Ca}^{-1}$, less than $10 \%$, between the coolest and the warmest year within the period 1981-2000 (Arneth, unpublished) when calculated with the CRU climatology (Mitchell and Jones, 2005). This variation includes not only the temperature and light effect on emissions, but also their effect on productivity and leaf area index. Clearly, the standard deviation of $c .50 \mathrm{Tg} \mathrm{Ca}^{-1}$ of published estimates to date could therefore be well accounted for by differences in the climatology used, whether or not the output is for a single year or a several-year period, or whether or not canopy temperature is used to drive simulations.

\subsection{Leaf developmental stage}

In addition to the sometimes notable short-term variation of emission capacity to weather conditions of the previous days, as observed in mature leaves (Sect. 3.3), does the capacity to emit isoprene in newly developing leaves lag behind the capacity to assimilate $\mathrm{CO}_{2}$ (Kuzma and Fall, 1993). The length of this lag phase depends on the growth temperature and may exceed ten days (Wiberley et al., 2005). For senescing leaves, a decline in emission capacity has been found (Monson et al., 1994; Schaab et al., 2003). Some global models account for this effect, either by assigning younger and older leaves lower emission capacities (Guenther et al., 2006; Lathière et al., 2006), or modelling emission capacity in deciduous trees as a function of growing degree day temperature sums (Arneth et al., 2007b). Both approaches lower emissions somewhat compared to models that do not account for this but the overall global scale effect should be small. Including the seasonality of emissions as represented in LPJ-GUESS (Arneth et al., 2007b; Schurgers et al., 2008) reduces the estimates on the global scale by little more than $5 \%$ but effects on regional scale emissions are much larger. In the current version of LPJ-GUESS, these seasonally varying estimates are restricted to deciduous PFTs. Clearly, as with many processes affecting emissions, models can only very rudimentarily ac- count for these, a wider range of controlled experiments as well as field observations that cover the entire active season are needed to provide a systematic basis for algorithm development and model evaluation.

\subsection{Top-down constraints for emission models}

A number of previous studies have shown that clear-sky space-borne formaldehyde (HCHO) columns can be used to quantitatively test current understanding of isoprene emissions on regional to continental spatial scales (e.g., Chance et al., 2000; Palmer et al., 2001; Palmer et al., 2003; Shim et al., 2005; Abbot et al., 2003). Most of these studies have used HCHO column data from GOME or -more recently- from the newer Ozone Monitoring Instrument (OMI) space-borne sensor aboard the NASA Aura satellite (Millet et al., 2006). The underlying idea is that because $\mathrm{HCHO}$ is generally a product of VOC oxidation, variations in $\mathrm{HCHO}$ column can provide information to map emissions of parent VOCs. The efficacy of this top-down approach relies on:

1. the parent VOC having a sufficiently short lifetime such that variations in $\mathrm{HCHO}$ columns can be related to local VOC emissions and

2. the parent VOC having a relatively high yield of $\mathrm{HCHO}$.

In the absence of horizontal transport, $\mathrm{HCHO}$ columns can be linearly related to VOC emissions, largely reflecting isoprene, the linear regression coefficients of which can be determined using an atmospheric chemistry model (Palmer et al., 2003). Horizontal transport smears the local relationship between VOC emissions and HCHO columns, the extent of which is determined by wind speed and the timedependent yield of HCHO from the VOC oxidation (Palmer et al., 2003). Aside from isoprene, other reactive biogenic VOCs, such as monoterpenes, also have short atmospheric lifetimes but they quickly produce acetone with a high yield that has an atmospheric lifetime of weeks and consequently slows down the production of HCHO (Palmer et al., 2006). Long-lived VOCs such as methane and methanol are the largest global sources of $\mathrm{HCHO}$ but their atmospheric lifetimes are such that they contribute only to its slowly-varying background levels.

Estimation of isoprene emissions from observed $\mathrm{HCHO}$ columns using the linear regression approach relies on prior assumptions associated with the oxidant chemistry relating isoprene and $\mathrm{HCHO}$, subject to considerable uncertainty particularly in environments with low-nitrogen oxide concentrations (Palmer et al., 2006). Regional studies using this approach generally demonstrate that isoprene emission derived from $\mathrm{HCHO}$ signals are broadly consistent with current model estimates of the spatial and temporal distributions of isoprene, but there are also some significant differences. For North America, early work showed that the magnitude and distribution of GOME-derived isoprene emissions were more 
consistent with in situ measurements than either the (G95 based) GEIA or BEIS2 (http://www.geiacenter.org/; http:// www.p2pays.org/ref\%5C07/06279.pdf) isoprene inventories (Palmer et al., 2003). Later work showed that the seasonal and year-to-year variability was consistent with MEGAN, but GOME isoprene emissions were higher (lower) at the beginning (end) of the growing season (Abbot et al., 2003; Palmer et al., 2006). GOME-derived isoprene emissions over south and east Asia $\left(49 \pm 26 \mathrm{Tg} \mathrm{Ca}^{-1}\right)$ were similar to those from MEGAN (46 $\mathrm{Tg} \mathrm{Ca}^{-1}$ ), but MEGAN overestimated emissions in the tropics and underestimated emissions in China, with important implications for ozone air quality (Fu et al., 2007). Analysis of GOME HCHO over tropical South America also concluded that MEGAN overestimated tropical isoprene emissions (25\%) and was only broadly consistent with the predicted spatial and temporal variations (Barkley et al., 2008 ${ }^{3}$ ) with better agreement in the dry season.

The study by Shim et al. (2005) currently represents the only global estimation of isoprene emissions using $\mathrm{HCHO}$ columns, in which they used an inversion approach to fit model estimates for biogenic and pyrogenic emissions to GOME observations of HCHO. This study used global a priori isoprene emissions of $375 \mathrm{Tg} \mathrm{C} \mathrm{a}^{-1}$ and calculated global annual a posteriori isoprene emissions of $566 \mathrm{Tg} \mathrm{Ca}^{-1}$, an increase of $50 \%$. The outcome of this work is sensitive to the balance of uncertainties assumed for the prior emissions and the observed $\mathrm{HCHO}$ columns. Without a more rigorous estimation of emissions and HCHO column uncertainties, or a sensitivity analysis of assumed uncertainties, it is difficult to determine the robustness of the a posteriori estimate. The inversion estimated emissions over relatively coarse spatial regions, reflecting in part the horizontal resolution of the GOME data $\left(40 \times 320 \times \mathrm{km}^{2}\right)$, so that the spatial distribution of a posteriori emissions within these regions is insensitive to the data. Most importantly, recent analysis of $\mathrm{HCHO}$ columns over South America has shown that fires are the largest source of $\mathrm{HCHO}$ across the region, often overlapping in time and space with biogenic sources (Barkley et al, 2008). It is not possible to separate these two sources without using coincident satellite measurements of nitrogen dioxide (large biomass burning source but small biogenic source) and firecounts which are subject to their own uncertainties. These considerations combined suggest not only that the Shim et al. isoprene estimates may need to be revisited but demonstrate also the difficult challenges facing the modelling community as it tries to reduce uncertainties in various components of the models conditioned on a narrow base of previous emission capacity estimates.

\footnotetext{
${ }^{3}$ Barkley, M. P., Palmer, P. I., Kuhn, U., Kesselmeier, J., Chance, K., Kurosu, T. P., Martin, R. V., Helmig, D., and Guenther, A.: Net ecosystem fluxes of isoprene over tropical South America inferred from GOME observations of HCHO columns, J. Geophys. Res., in review, 2008.
}

\section{Illusion or chaos?}

The above examples clearly identify how a small variation in either the emission model drivers or the process representation can, without difficulty, introduce a variation in the calculated annual isoprene totals that is equal to or larger than the standard deviation around the mean of estimates to date. In a nutshell, as discussed in section three, the single most important parameterisation is the assignment of PFT emission capacities, since emissions depend linearly on the values chosen (Eqs. 1 and 2). It also becomes clear that variation in model process description and environmental drivers can each affect global totals easily by $10 \%$, often more. However, the information provided in the published literature is not sufficient to quantitatively discuss the uncertainties in isoprene or monoterpene emission estimates that may be introduced by a certain factor. Variation caused by each of these can move estimates both up or down compared to the unknown "true" global total and a pattern of compensation among model experiments can therefore be expected. We question here, however, why such a compensation should always take place, and why it should be present for isoprene but not for monoterpenes. With no observational constraints on global emissions should one not expect some simulations to diverge rather than converge, resulting in an overall much greater difference to the "truth"? Furthermore, what causes the much larger variation of global monoterpene emissions, with estimates varying by a factor of four between minimum and maximum even when effects of different algorithms are not included, rather than by a factor of 1.46 as for isoprene? There is no apparent reason why the spread in monoterpene emission rates should be so much larger compared to isoprene emission rates. Both are based on similar model set experiments and differences in vegetation type, physiological activity or canopy characteristics should have very similar effects for isoprene and monoterpene emissions; the studies listed in Table 1 also do not differ any more in terms of their assigned emission capacities of monoterpenes than they do for isoprene.

In a recent publication, Le Quéré (2006) identified three chief phases in model development, "the illusion, the chaos and the relief". Adopting her views, that were developed for carbon cycle and climate modelling, we argue that the modelling of BVOC emissions is in the illusion phase: lack of observations prevent independent model evaluation and the models have the propensity to not depart greatly from previously published estimates (Le Quéré, 2006). Whereas in the case of monoterpenes, simulations appear to have moved readily into the chaos phase where model results diverge freely, reflecting more candidly the lack of observational constraints and of true process understanding. One may speculate how the still rather basic parameterisation of atmospheric models in terms of SOA chemistry, for which monoterpenes are an important source, may support the larger openness towards variation between models since 
the pressure of confirming previously published estimates is lower.

Inversions of remote sensing information can provide only a top-down modelling constraint on BVOC emissions rather than an observation. Therefore, while global constraints on emissions are absent we encourage the modelling community to explore the chaos phase in the simulations more freely. Without doing so the wrong impression of isoprene modelling entering the phase of "relief" may emerge. The notion that today's process-understanding and representation of basic concepts in models or their evaluation against observations could be sufficient to support a consensus on emission totals (and their response to global change) is unfounded. This state of affairs is counterproductive: a phase of exploration in models can only be regarded as highly beneficial, for model development but more importantly, for revealing the urgent need of further observations. The "race ahead" of modellers beyond observational evidence (Monson et al., 2007) could therefore be regarded as a fruitful exercise. Critically, however, modellers must resist the temptation to tune their models to perceived "truths" and be ready to explore and publish model sensitivities to a much larger degree, and to explore model-to-model differences more systematically in intercomparisons. This approach would rapidly lead to the realisation that global terrestrial emissions are an unknown rather than an uncertain number.

Acknowledgements. This work is supported by a European Commissions 6th FP Marie Curie Excellence Team grant, by the Swedish Research Council and by the Human Frontier Science Programme. The authors acknowledge discussions at the VOCBAS science meeting in Montpellier and the Marie-Curie iLEAPs meeting in Helsingborg to stimulate the development of this manuscript. Comments by two anonymous reviewers helped greatly to improve the paper.

Edited by: J. Rinne

\section{References}

Abbot, D. S., Palmer, P. I., Martin, R. V., Chance, K. V., Jacob, D. J., and Guenther, A.: Seasonal and interannual variability of North American isoprene emissions as determined by formaldehyde column measurements from space, Geophys. Res. Lett., 30, 1886, doi:10.1029/2003GL017336, 2003.

Adams, J. M., Constable, J. V. H., Guenther, A. B., and Zimmerman, P.: An estimate of natural volatile organic compound emissions from vegetation since the last glacial maximum, Chemosphere, 3, 73-91, 2001.

Arneth, A., Miller, P., Scholze, M., Hickler, T., Smith, B., and Prentice, I. C.: $\mathrm{CO}_{2}$ inhibition of global terrestrial isoprene emissions: Potential implications for atmospheric chemistry, Geophys. Res. Lett., 34, L18813, doi:18810.11029/12007GL030615, 2007a.

Arneth, A., Niinemets, Ü., Pressley, S., Bäck, J., Hari, P., Noe, S., Prentice, I. C., Serça, D., Hickler, T., and Wolf, A.: Processbased estimates of terrestrial ecosystem isoprene emissions: In- corporating the effects of a direct $\mathrm{CO}_{2}$-isoprene interaction, Atmos. Chem. Phys., 7, 31-53, 2007,

http://www.atmos-chem-phys.net/7/31/2007/.

Arneth, A., Schurgers, G., Miller, P., and Hickler, T.: Effects of species composition, land surface cover, $\mathrm{CO}_{2}$ concentration and climate on isoprene emissions from European forests, Plant Biology, 10(1), 150-162, 2008.

Ashmore, M. R.: Assessing the future global impacts of ozone on vegetation, Plant, Cell and Environment, 28, 949-964, 2005.

Atkinson, R.: Atmospheric chemistry of VOCs and $\mathrm{NO}_{\mathrm{x}}$, Atmospheric Environment, 34, 2063-2101, 2000.

Atkinson, R. and Arey, J.: Gas-phase tropospheric chemistry of biogenic volatile organic compounds: A review, Atmos. Environ., 37, 197-219, 2003.

Bai, J., Baker, B., Liang, B., Greenberg, J. and Guenther, A.: Isoprene and monoterpene emissions from an inner Mongolia grassland, Atmos. Environ., 40, 5753-5758, 2006.

Chance, K., Palmer, P. I., Spurr, R. J. D., Martin, R. V., Kurosu, T. P., and Jacob, D. J.: Satellite observations of formaldehyde over north America from GOME, Geophys. Res. Lett., 27, 34613464, 2000.

Claeys, M., Graham, B., Vas, G., Wang, W., Vermeylen, R., Pashynska, V., Cafmeyer, J., Guyon, P., Andreae, M. O., Artaxo, P., and Maenhaut, W.: Formation of secondary organic aerosols through photooxidation of isoprene, Science, 303, 1173-1176, 2004.

Cramer, W., Kicklighter, D. W., Bondeau, A., III, B. M., Churkina, G., Nemry, B., Ruimy, A., Schloss, A. L., and the the participants of the Potsdam NPP Model Intercomparison: Comparing global models of terrestrial net primary productivity (NPP): Overview and key results, Global Change Biology, 5(S1), 1-15, 1999.

Derwent, R. G.: Air chemistry and terrestrial gas emissions: A global perspective, Philosophical Transactions of the Royal Society of London: Phys. Sci. Eng., 351, 205-217, 1995.

Forster, P., Ramaswamy, V., Artaxo, P., Berntsen, T., Betts, R., Fahey, D. W., Haywood, J., Lean, J., Lowe, D. C., Myhre, G., Nganga, J., Prinn, R., Raga, G., Schultz, M., van Dorland, R., et al.: Changes in atmospheric constituents and radiative forcing, in: Climate Change 2007: The Physical Science Basis, contribution of Working Group I to the Fourth Assesment Report of the Intergovernmental Panel on Climate Change, edited by: Solomon, S., Qin, D., Manning, M., Chen, Z., Marquis, M., Averyt, K. B., Tignor, M., and Miller, H. L., Cambridge University Press, Cambridge, UK and New York, USA, 2007.

Fu, T. M., Jacob, D. J., Palmer, P. I., Chance, K., Wang, Y. X., Barletta, B., Blake, D. R., Stanton, J. C., and Pilling, M. $\mathrm{J}$.: Space-based formaldehyde measurements as constraints on volatile organic compound emissions in east and south asia and implications for ozone, J. Geophys. Res.-Atmos., 112, D06312, doi:10.1029/2006JD007853, 2007.

Geron, C., Guenther, A., Sharkey, T. D., and Arnts, R. R.: Temporal variability in basal isoprene emission factor, Tree Physiology, 20, 799-805, 2000.

Greenberg, J. P., Guenther, A., Harley, P., Otter, L., Veenendaal, E. M., Hewitt, C. N., James, A. E., and Owen, S. M.: Eddy flux and leaf-level measurements of biogenic voc emissions from Mopane woodland of Botswana, J. Geophys. Res.-Atmos., 108, 8466, doi:10.1029/2002JD002317, 2003.

Guenther, A.: Seasonal and spatial variations in natural volatile organic compound emissions, Ecol. Appl., 7, 34-45, 1997. 
Guenther, A., Zimmerman, P. R., Harley, P. C., Monson, R. K., and Fall, R.: Isoprene and monoterpene emission rate variability model evaluations and sensitivity analyses, J. Geophys. Res., 98, 12 609-12 617, 1993.

Guenther, A., Hewitt, C. N., Erickson, D., Fall, R., Geron, C., Graedel, T., Harley, P., Klinger, L., Lerdau, M., McKay, W. A., Pierce, T., Scholes, B., Steinbrecher, R., Tallamraju, R., Taylor, J., and Zimmermann, P.: A global model of natural volatile organic compound emissions, J. Geophys. Res.-Atmos., 100, 8873-8892, 1995.

Guenther, A., Baugh, B., Brasseur, G., Greenberg, J., Harley, P., Klinger, L., Serça, D., and Vierling, L.: Isoprene emission estimates and uncertainties for the central African Expresso study domain, J. Geophys. Res., 104, 30 635-30 639, 1999.

Guenther, A., Karl, T., Harley, P., Wiedinmyer, C., Palmer, P. I., and Geron, C.: Estimates of global terrestrial isoprene emissions using MEGAN (model of emissions of gases and aerosols from nature), Atmos. Chem. Phys., 6, 3181-3210, 2006, http://www.atmos-chem-phys.net/6/3181/2006/.

Hanson, D. T. and Sharkey, T. D.: Rate of acclimation of the capacity for isoprene emission in response to light and temperature, Plant, Cell and Environment, 24, 937-946, 2001.

Hakola, H., Rinne, J., and Laurila, T.: The hydrocarbon emission rates of tea-leafed willow (salix phylicifolia), silver birch (betula pendula) and european aspen (populus tremula), Atmos. Environ., 32, 1825-1833, 1998.

Henze, D. and Seinfeld, J. H.: Global secondary organic aerosol from isoprene oxidation, Geophys. Res. Lett., 33, L09812, doi:09810.01029/02006GL025976, 2006.

Hickler, T., Smith, B., Prentice, I. C., Mjö, K., Miller, P., Arneth, A., and Sykes, M.: $\mathrm{CO}_{2}$ fertilization in temperate face experiments not representative of boreal and tropical forests, Global Change Biol., 14, 1-12, 2008.

Hoffmann, T., Odum, J. R., Bowman, F., Collins, D., Klockow, D., Flagan, R. C., and Seinfeld, J. H.: Formation of organic aerosols from the oxidation of biogenic hydrocarbons, J. Atmos. Chem., 26, 189-222, 1997.

Janson, R. and de Serves, C.: Acetone and monoterpene emissions from the boreal forest in northern europe, Atmos. Environ., 35, 4629-4637, 2001.

Kaplan, J. O., Folberth, G., and Hauglustaine, D. A.: Role of methane and biogenic volatile organic compound sources in late glacial and Holocene fluctuations of atmospheric methane concentrations, Global Biogeochem. Cy., 20, GB2016, doi:10.1929/2005GB002590, 2006.

Kesselmeier, J. and Staudt, M.: Biogenic volatile organic compounds (VOC): an overview on emission, physiology and ecology, J. Atmos. Chem., 33, 23-88, 1999.

Kuhn, U., Rottenberger, S. T. B., Wolf, A. G. S., Ciccioli, P., Brancaleoni, E., Frattoni, M., Tavares, T. M., and Kesselmeier, J.: Seasonal differences in isoprene and light-dependent monoterpene emission by Amazonian tree species, Global Change Biol., 10, 663-682, 2004.

Kulmala, M.: How particles nucleate and grow, Science, 302, 1000 1001, 2003.

Kuzma, J. and Fall, R.: Leaf isoprene emission rate is dependent on leaf development and the level of isoprene synthase, Plant Physiol., 101, 435-440, 1993.

Lamb, B., Pierce, T., Baldocchi, D., Allwine, E., Dilts, S., West- berg, H., Geron, C., Guenther, A., Klinger, L., Harley, P., and Zimmerman, P.: Evaluation of forest canopy models for estimating isoprene emissions, J. Geophys. Res., 101, 22 787-22 797, 1996.

Lathière, J., Hauglustaine, D. A., Friend, A., De Noblet-Ducoudré, N., Viovy, N., and Folberth, G.: Impact of climate variability and land use changes on global biogenic volatile organic compound emissions, Atmos. Chem. Phys., 6, 2199-2146, 2006, http://www.atmos-chem-phys.net/6/2199/2006/.

Le Quéré, C.: The unknown and the uncertain in earth system modeling, Eos T Am. Geophys. Un., 87, 496-496, 2006.

Leemans, R. and Cramer, W.: IIASA database for mean monthly values of temperature, precipitation, and cloudiness on a global terrestrial grid: Digital raster on a 30 minute geographic (lat/long) 320 times 720 grid, NOAA National Geophysical Data Center, Global Ecosystems Database Version 1.0, Disc A, 1992.

Levis, S., Foley, J. A., and Pollard, D.: Potential high-latitude vegetation feedbacks on co2-induced climate change, Geophys. Res. Lett., 26, 747-750, 1999.

Levis, S., Wiedinmyer, C., Bonan, G. B., and Guenther, A.: Simulating biogenic volatile organic compound emissions in the community climate system model, J. Geophys. Res.-Atmos., 108, 4659, doi:4610.1029/2002JD003203, 2003.

Liao, H., Cheng, W.-T., and Seinfeld, J. H.: Role of climate change in global predictions of future tropospheric ozone and aerosols, J. Geophys. Res.-Atmos., 111, D12304, doi:12310.11029/12005JD006852, 2006.

Lichtenthaler, H. K., Schwender, J., Disch, A., and Rohmer, M.: Biosynthesis of isoprenoids in higher plant chloroplasts proceeds via a mevalonate-independent pathway, FEBS Lett., 400, $271-$ 274, 1997.

Loreto, F. and Velikova, V.: Isoprene produced by leaves protects the photosynthetic apparatus against ozone damage, quenches ozone products, and reduces lipid peroxidation of cellular membranes, Plant Physiol., 127, 1781-1787, 2001.

Loreto, F. and Fares, S.: Is ozone flux inside leaves only a damage indicator?: clues from volatile isoprenoid studies, Plant Physiol., 143, 1096-1100, 2007.

Millet, D. B., Jacob, D. J., Turquety, S., Hudman, R. C., Wu, S. L., Fried, A., Walega, J., Heikes, B. G., Blake, D. R., Singh, H. B., Anderson, B. E., and Clarke, A. D.: Formaldehyde distribution over north America: Implications for satellite retrievals of formaldehyde columns and isoprene emission, J. Geophys. Res.Atmos., 111, D24S02, doi:10.1029/2006JD007287, 2006.

Mitchell, T. D. and Jones, P. D.: An improved method of constructing a database of monthly climate observations and associated high-resolution grids, Int. J. Climatol., 25, 693-712, 2005.

Monson, R., Harley, P., Litvak, M. E., Wildermuth, M., Guenther, A., Zimmerman, P. R., and Fall, R.: Environmental and developmental controls over the seasonal pattern of isoprene emission from aspen leaves, Oecologia, 99, 260-270, 1994.

Monson, R. K., Jaeger, C. H., Adams, W. W. I., Driggers, E. M., Silver, G. M., and Fall, R.: Relationship among isoprene emission rate, photosynthesis, and isoprene synthase activity as influenced by temperature, Plant Physiol., 98, 1175-1180, 1992.

Monson, R. K., Trahan, N., Rosenstiel, T. N., Veres, P., Moore, D. Wilkinson, M., Norby, R. J., Volder, A., Tjoelker, M. G., Briske, D. D., Karnosky, D. F., and Fall, R.: Isoprene emission from terrestrial ecosystems in response to global change: Minding the 
gap between models and observations, Philos. T. Roy. Soc. A, 365, 1677-1695, 2007.

Monteith, J. L. and Unsworth, M.: Principles of environmental physics, 2nd ed., Arnold, London, UK, 1990.

Mueller, J. F.: Geographical-distribution and seasonal variation of surface emissions and deposition velocities of atmospheric trace gases, J. Geophys. Res.-Atmos., 97, 3787-3804, 1992.

Naik, V., Delire, C., and Wuebbles, D. J.: Sensitivity of global biogenic isoprenoid emissions to climate variability and atmospheric $\mathrm{CO}_{2}$, J. Geophys. Res.-Atmos., 109, D06301, doi:06310.01029/02003JD004236, 2004.

Niinemets, U., Tenhunen, J. D., Harley, P. C., and Steinbrecher, R.: A model of isoprene emission based on energetic requirements for isoprene synthesis and leaf photosynthetic properties for Liquidambar and Quercus, Plant Cell Environ., 22, 13191335, 1999.

Olson, J.: World ecosystems (WE1.4): digital raster on a 10 minute geographic $1080 \times 2160$ grid, NOAA National Geophysical Data Center, Global ecosystems database, Version 1.0, Disc A, 1992.

Palmer, P. I., Jacob, D. J., Chance, K., Martin, R. V., Spurr, R. J. D., Kurosu, T. P., Bey, I., Yantosca, R., Fiore, A., and Li, Q. B.: Air mass factor formulation for spectroscopic measurements from satellites: Application to formaldehyde retrievals from the global ozone monitoring experiment, J. Geophys. Res.-Atmos., 106, 14 539-14 550, 2001.

Palmer, P. I., Jacob, D. J., Fiore, A. M., Martin, R. V., Chance, K., and Kurosu, T. P.: Mapping isoprene emissions over North America using formaldehyde column observations from space, J. Geophys. Res.-Atmos., 108, 4180, doi:10.1029/2002JD002153, 2003.

Palmer, P. I., Abbot, D. S., Fu, T. M., Jacob, D. J., Chance, K., Kurosu, T. P., Guenther, A., Wiedinmyer, C., Stanton, J. C., Pilling, M. J., Pressley, S. N., Lamb, B., and Sumner, A. L.: Quantifying the seasonal and interannual variability of North American isoprene emissions using satellite observations of the formaldehyde column, J. Geophys. Res.-Atmos., 111, D12315, doi:10.1029/2005JD006689, 2006.

Potter, C. S., Alexander, S. E., Coughlan, J. C., and Klooster, S. A.: Modeling biogenic emissions of isoprene: Exploration of model drivers, climate control algorithms, and use of global satellite observations, Atmos. Environ., 35, 6151-6165, 2001.

Possell, M., Hewitt, N. C., and Beerling, D. J.: The effects of glacial atmospheric $\mathrm{CO}_{2}$ concentrations and climate on isoprene emissions by vascular plants, Global Change Biol., 11, 60-69, 2005.

Prather, M., Ehhalt, D., Dentener, F. J., Derwent, R., Dlugokencky, E. J., Holland, E., Isaksen, I., Katima, J., Kirchhoff, V., Matson, P., Midgley, P. et al.: Atmospheric chemistry and greenhouse gases, in: Climate change 2001: the scientific basis, Contribution of working group I to the Third Assessment Report of the Intergovernmental Panel on Climate Change, edited by: Houghton, J. T., Ding, Y., Griggs, D. J., Noguer, M., van der Linden, P. J., Dai, X., Maskell, K., and Johnson, C. A., Cambridge University Press, Cambridge, UK, 238-287, 2001.

Rinne, J., Tuovinen, J. P., Laurila, T., Hakola, H., Aurela, M., and Hypen, H.: Measurements of hydrocarbon fluxes by a gradient method above a northern boreal forest, Agr. Forest Meteorol., 102, 25-37, 2000.

Rosenstiel, T. N., Potosnak, M. J., Griffin, K. L., Fall, R., and Monson, R. K.: Increased $\mathrm{CO}_{2}$ uncouples growth from isoprene emis- sion in an agriforest ecosystem, Nature, 421, 256, 2003.

Sanderson, M. G., Jones, C. D., Collins, W. J., Johnson, C. E., and Derwent, R. G.: Effect of climate change on isoprene emissions and surface ozone levels, Geophys. Res. Lett., 30, 1936, doi:1910.1029/2003GL017642, 2003.

Schaab, G., Steinbrecher, R., and Lacaze, B.: Influence of seasonality, canopy light extinction, and terrain on potential isoprenoid emission from a mediterranean-type ecosystem in france, J. Geophys. Res.-Atmos., 108, 4392, doi:4310.1029/2002JD002899, 2003.

Shim, C., Wang, Y., Choi, Y., Palmer, P., Abbot, D., and Chance, K.: Constraining global isoprene emissions with global ozone monitoring experiment (GOME) formaldehyde column measurements, J. Geophys. Res.-Atmos., 110, D24301, doi:24310.21029/22004JD005629, 2005.

Shindell, D. T., Faluvegi, G., and Bell, N.: Preindustrial-to-presentday radiative forcing by tropospheric ozone from improved simulations with the GISS chemistry-climate GCM, Atmos. Chem. Phys., 3, 1675-1702, 2003,

http://www.atmos-chem-phys.net/3/1675/2003/.

Sitch, S., Smith, B., Prentice, I. C., Arneth, A., Bondeau, A., Cramer, W., Kaplan, J. O., Levis, S., Lucht, W., Sykes, M. T., Thonicke, K., and Venevsky, S.: Evaluation of ecosystem dynamics, plant geography and terrestrial carbon cycling in the LPJ dynamic global vegetation model, Global Change Biol., 9, 161185, 2003.

Sitch, S., Cox, P. M., Collins, W. J., and Huntingford, C.: Indirect radiative forcing of climate change through ozone effects on the land-carbon sink, Nature, 448, 791-794, 2007.

Smith, B., Prentice, I. C., and Sykes, M. T.: Representation of vegetation dynamics in the modelling of terrestrial ecosystems: Comparing two contrasting approaches within european climate space, Global Ecol. Biogeogr., 10, 621-637, 2001.

Staudt, M. and Seufert, G.: Light-dependent emission of monoterpenes by holm oak (Quercus ilex 1.), Naturwissenschaften, 82, 89-92, 1995.

Stevenson, D. S., Dentener, F. J., Schultz, M. G., Ellingsen, K., van Noije, T. P. C., Wild, O., Zeng, G., Amann, M., Atherton, C. S., et al.: Multi-model ensemble simulations of present-day and near-future tropospheric ozone, J. Geophys. Res.-Atmos., 111, D08301, doi:10.1029/2005JD006338. 2006.

Tao, Z. and Jain, A. K.: Modeling of global biogenic emissions for key indirect greenhouse gases and their response to atmospheric $\mathrm{CO}_{2}$ increases and changes in land cover and climate, J. Geophys. Res.-Atmos., 110, D21309, doi:10.1029/22005JD005874, 2005.

Tunved, P., Hansson, H. C., Kerminen, V. M., Strom, J., Maso, M. D., Lihavainen, H., Viisanen, Y., Aalto, P. P., Komppula, M., and Kulmala, M.: High natural aerosol loading over boreal forests, Science, 312, 261-263, 2006.

Turner, D. P., Baglio, J. V., Wones, A. G., Pross, D., Vong, R., McVeety, B. D., and Phillips, D. L.: Climate change and isoprene emissions from vegetation, Chemosphere, 23, 37, 1991.

Valdes, P. J., Beerling, D. J., and Johnson, D. E.: The ice age methane budget, Geophys. Res. Lett., 32, L02704, doi:10.1029/02004GL021004, 2005.

Velikova, V., Pinelli, P., Pasqualini, S., Reale, L., Ferranti, F., and Loreto, F.: Isoprene decreases the concentration of nitric oxide in leaves exposed to elevated ozone, New Phytol., 166, 419-426, 
2005.

Wang, K. Y. and Shallcross, D. E.: Modelling terrestrial biogenic isoprene fluxes and their potential impact on global chemical species using a coupled LSM-CTM model, Atmos. Environ., 34, 2909-2925, 2000.

Wang, Y., Jacob, D. J., and Logan, J. A.: Global simulation of tropospheric $\mathrm{O}_{3}-\mathrm{NO}_{\mathrm{x}}$-hydrocarbon chemistry - 1: Model formulation, J. Geophys. Res.-Atmos., 103, 10 713-10 726, 1998.

Wiberley, A. E., Linskey, A. R., Falbel, T. G., and Sharkey, T. D.: Development of the capacity for isoprene emission in kudzu, Plant Cell Environ., 28, 898-905, 2005.
Wiedinmyer, C., Guenther, A., Harley, P., Hewitt, C., Geron, C., Artaxo, P., Steinbrecher, R., and Rasmussen, R.: Global organic emissions from vegetation, in: Emissions of atmospheric trace compounds, edited by: Granier, C., Kluwer Publishing C., Dordrecht, The Netherlands, 121-182, 2004.

Wiedinmyer, C., Tie, X., Guenther, A., Neilson, R., and Granier, C.: Future changes in biogenic isoprene emissions: How might they affect regional and global atmospheric chemistry?, Earth Interactions, 10, 1-19, 2006. 